International Journal of Agriculture, Environment and Bioresearch

Vol. 4, No. 03; 2019

ISSN: $2456-8643$

\title{
EEFECT OF WET AND DRY FEED ON THE GROWTH PERFORMANCE OF EARLY - WEANED PIGLETS
}

\author{
Nwakpu P.E And Ucheji. C.C \\ Department Of Animal Science, Ebonyi State University, Abakaliki, Ebonyi State - Nigeria \\ http://doi.org/10.35410/IJAEB.2019.4752
}

\begin{abstract}
Five weeks old piglets weighting between 5-6kg were used to conduct a trial on the effect of wet and dry feed on their early growth performance. Forty piglets were used for this trial and twenty piglets each were assigned to one of the two diets whose crude protein is $18.90 \%$ and metabolizable energy of $2650 \mathrm{kcal} / \mathrm{kg}$ respectively. The piglets were randomly allotted to the two dietary treatments A (dry mash) and B (wet mash). Each treatment consisted of four replicates with five piglets per replicate. The mean daily feed intake, water consumption, body weight gain and feed conversion efficiency values were monitored and showed significant differences $(\mathrm{p}<0.05)$ between treatments. Considering the temperature, time expended on dry feed by the young piglets, the effectiveness of utilization as well as the case of preparing the wet mash, their use in early weaning of piglets by farmers in the tropics offers wonderful benefits for delivering them to the piglets are available.
\end{abstract}

Keywords: Wet, Dry, Piglets, growth performance, Early-weaned.

\section{INTRODUCTION}

In Nigeria, piggery diets are normally fed as dry mash. Feed texture characteristics such as hardness, fragility charring work and adhesiveness influence the palatability of diets fed to young pigs Sola-Oriol et al., 2009b)

Liquid feeding involves the use of diet prepared either from a mixture of liquid food industrial by-products and conventional dry materials, or from dry raw materials mixed with water. Wetting the mash by mixing with twice the weight of water to give a porridge-like consistency is said to increase feed intake, body weight gain and food conversion efficiency (Yalda and Forbes, 1995). By mixing with water, lactic acid bacteria and yeasts naturally occurring in various feed ingredients preliferate and produce lactic acid, acetic acid and ethanol which reduce $\mathrm{pH}$ of the mixture (Canibe and Jensen,2012). This reduction in $\mathrm{pH}$ inhibits pathogenic organisms from developing in the feed. In addition, when this low $\mathrm{PH}$ mixture is fed, it reduces the $\mathrm{pH}$ in the stomach of pigs and prevents the proliferation of pathogens such as Coli forms and Salmonella from developing in the gastrointestinal tract (Canibe and Jensen, 2012).

Unfortunately, pig feeding in Nigeria is influenced considerably by a number of specific factors like low technical expertise of farmers, poorly organized markers for both animal and feeds, 


\section{International Journal of Agriculture, Environment and Bioresearch}

Vol. 4, No. 03; 2019

ISSN: $2456-8643$

almost lack of fed industry, wide variability in carcass quality required and high cost of imported materials.

The adult pigs can handle rough diets but for the early-weaned piglets, grinding is absolutely essential especially as their molars are not properly functional. This is because grinding ensures homogeneity. Nevertheless, grinding must give fine grist for the animals to be able to digest their diets. Nutrient digestibility may be improved, if the grain in the diet is grand to average

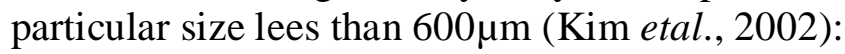

However, a fine grit cost much to produce and output from the grinder is reduce. Secondly fine feeds are association with considerable losses during manufacture in the form of dust which is blown away and most seriously, it is understood that finely ground feed promote the development of gastro duodenal ulcers which are more common than thought. Feed is one of the factors responsible for poor growth among piglets (Ogbinne etal., 2001).

It is also important to note that pigs do not like feeds too finely ground because as they breathe while they eat, it makes them sneeze frequently. This is one of the reason why some poultry feeds are pelletized and for pigs moistened. Pelletizing pig diets is expensive and cannot be afforded by many pig farmers.

In order to forestall the problems associated with ground feed for our piglets especially early weaned piglets, a study was therefore designed to investigate the effect of adding water to mash diet in the ratio of 2:1 (water to feed on a volume basis) on the performance of pre-weaned piglets.

Our belief is that, moistening / wetting the diet of young piglets will help to reduce losses due to dust, feed selection and above all improve their food utilization.

\section{MATERIALS AND METHOD}

Three weeks - old piglets weighing between 5-6kg were used for this study, which lasted for 35days. This study was carried out at the piggery teaching and research farm of Ebonyi State University, Abakaliki.

Two diets containing such ingredient as cassava peel meal, wheat offal's maize offals, soybeans cake, groundnut cake, bone meal, salt and premixes were formulated, mixed on the poor pegged and stored at room temperature. Two samples were taken for proximate analysis (AOAC, 1980) after compounding and results are shown in Table 3. Piglets were fed the dry mash 7 days after which they were weighed individually and then randomly allotted to the two dietary treatments A (dry mash) and B (wet mash). The wet mash was obtained by daily mixing the air dry mash with twice the weight of water before feeding. Each treatment consisted of four replicates with two piglets per replicate.

Feeding was done twice daily while water was supplied ad-libitum to the piglets. The piglets were dewormed once and provided with other prophylactic treatments during the experiment. The parameters measured include feed intake, water intake, weight gains as well as efficiency of 
Vol. 4, No. 03; 2019

ISSN: $2456-8643$

feed utilization. Data were recorded on a weekly basis from which the mean daily records were calculated. Pooled data from replicates were subjected to T-test statistics.

\section{RESULTS}

The proximate composition of the experimental diets is shown on Table 3. The results of the performance of the piglets (Table 2) indicate that significant differences $(p<0.05)$ existed between the treatments. Treatment A (dry mash) had lower mean daily feed intake value $380 \mathrm{~g} /$ piglet on dry matter basis than treatment B (wet mash) which has $740 \mathrm{~g} /$ piglet. A higher mean value of $500 \mathrm{~g} /$ piglet for daily weight gain was recorded from treatment B (wet mash)than on A (300g/piglet). Treatment A piglets recorded a higher $(\mathrm{p}<0.05)$ mean value of (3000ml/piglet)for daily water intake than the treatment B (200ml/piglet). The piglets on treatment B had a better feed $(\mathrm{p}<0.05)$ conversion efficiency $(1.48)$ than those on treatment A (1.27).

\section{DISCUSSION}

The results of this study indicate unequivocally that wet or moist mash significantly $(\mathrm{p}<0.05)$ improved dry matter intake. This observation agrees with the earlier report of Yalda and Forbes (1995) in evaluating the effect of enzyme and corn flour addition on the performance and digestion of dry and wet by broilers observed that dry matter intake increased with wet feeding working on broiler growth and efficiency with wet feed under semi-commercial conditions. Yalda et al. (1995) discovered that providing conventional poultry feeds mixed with 1.6 to 2.0 times their weight of water resulted in significantly $(\mathrm{p}<0.05)$ lower intakes of dry feed compared with the wet feed treatments throughout the period of experiment.

In their own study, El kash and Forbes (1995) indicated that mixing 1.5 to 2.0 times the weight of water per unit feed significantly $(\mathrm{p}<0.05)$ improved body weight gain of the chickens. Similarly, McCrackenet al. (1994) observed that dry matter intake, body weight gain and gain to feed ratio were markedly reduced for dry mash diets compared to with the wet diets. In the same vein, Nwakpu et al. (1999 and 2000) observed that dry matter intake with slight increase in feed refusal arising from spoilages in the mash feed. The case of feed refusal did not arise in our own study since the piglets were willing to eat even more than provided.

Ogbonna et al. (1996 and 2001) observed that feeding dry mash compared with wet mash significantly (p.0.05)reduced feed intake, body weight gain and feed to gain ratio. Nwakpu and Otuma (2006) related the effects of moist or wetting on feed intake and body weight gain to the degree of moistening and noted that feed utilization is improved by wetting the independent of the amount consumed Partridgeet al (1992; Yalda and Forbes (1995; Choct et al, 2004b). Han et al (2006): reported that pigs fed diets in a liquid form usually have improved daily gain and feed efficiency compared with pigs fed diets in a meal. This is true owing to fact that the piglets spent less time feeding on wet mash and so expended less energy than they did for the air dry mash (Nwakpu and Otuma, 2006). 
The observations of these workers support the findings in the present study. The addition of water to the dry mash before feeding the piglets helped in reducing the dustiness and fluffiness of the air dry mash which made it "pellet-like"with the resultant higher dry matter intake, more weight gain and better efficiency than piglets on dry mash.

Table 1: Composition of Experimental Diets

\begin{tabular}{|lc|}
\hline Ingredients & Percentages \\
\hline Cassava peel meal & 45.00 \\
Wheat offal & 18.00 \\
Maize offal & 5.00 \\
Soyabean cake & 10.00 \\
Groundnut cake & 15.00 \\
Fish meal & 5.00 \\
Bone meal & 1.00 \\
Salt & 0.50 \\
Premixes & 0.50 \\
Total & $\mathbf{1 0 0 . 0 0}$ \\
\hline
\end{tabular}

Table 2: Proximate Composition of the Experimental diets

Ingredients

Dry matter

Crude protein

Crude fibre

Nitrogen Free Extract

$\mathrm{ME}(\mathrm{Kcal} / \mathrm{kg})$

\section{Percentages}

\subsection{5}

21.50

10.70

17.30

2.70

A vitamin, trace mineral mix manufactured by Pliper feed which contains the following $/ \mathrm{kg}$ : Vit A 10000iu; Vit. D 20,000iu; Vit. E2.5mg; Vit. K 20mg; riboflavin 4.2mg;20mg; Pantothenic acid 5mg; nicotinic acid Chlorine-mg; Folic acid 5mg; methoionine $0.225 \mathrm{mg}$; Mn 56mg; Iodine 1mg; Fe 20mg; Cu 10mg; Zn 50mg;Cobalt $1.25 \mathrm{mg}$.

Table 3: Performance characteristic of weaned piglets

\begin{tabular}{|lccc|}
\hline \multicolumn{3}{|c|}{ Item } & Treatment \\
\hline Mean Daily feed intake & A(Dry) & B(Wet) & SEM \\
(Dm basis kg/piglet) & $380 \mathrm{~b}$ & $740 \mathrm{a}$ & 0.20 \\
Mean Daily water intake (Lc/piglet) & $3000 \mathrm{a}$ & $2000 \mathrm{~b}$ & 0.80 \\
Mean Daily weight gain (g/piglet) & $300 \mathrm{~b}$ & $500 \mathrm{a}$ & 0.50 \\
Feed efficiency & 1.27 & 1.48 & 0.80 \\
\hline
\end{tabular}

$\mathrm{a}, \mathrm{b}$; Means not followed by same superscripts are not statistically $(\mathrm{p}<0.05)$ different 


\section{International Journal of Agriculture, Environment and Bioresearch}

Vol. 4, No. 03; 2019

ISSN: $2456-8643$

The performance of piglets indicate that significant differences occure between the treatment with a lower mean daily Feed intake value $380 \mathrm{~g} /$ piglet on dry matter basis for treatment B (dry mash) than wet mash which has $740 \mathrm{~g} /$ piglet. The result was in line with the report of Dong and Pluske, (2007) who reported that liquid diets results in increase feed intake which induces a healthier and more intake villi-structure in the small intestine. Pig fed liquid feed had higher weight gain $(500 \mathrm{~g})$ than pig offered dry mash $(300 \mathrm{~g})$. This result agrees with previous research demonstrating an increase in feed intake as a result of liquid feeding after weaning (Kornegay et al., 1981; Partridge et al., 1992; Lawlor et al., 2002; Yalda and Forbes 1995; Chock et al, 2004b and Kim et al., 2002 Han et al, 2006).The improvement intake seen with wet feeding has been suggested to be behaviourally based due to the fact that the newly weaned pig does not have to learn new and separating feeding and drinking behavior immediately following weaning (Thanker, 1998).

Pigs Fed liquid feed had a higher feed conversion (1.48) than pigs offered dry feed (1.27). This result was in agreement with Han (2006)who reported that pigs fed diets in a liquid form usually have improved daily gain and feed efficiency compared with pig fed diets in a meal form.

The higher feed intake of pigs fed liquid feed generally was associated with higher weight gain.

\section{CONCLUSION}

The use of wet mash in pig diets has a lot of benefits than dry mash and this appears to provide an opening into exploring its commercial benefits particularly in the tropics especially if suitable equipments for mixing and delivering it to the pigs are developed.

\section{REFERENCES}

Association of Official Analytical Chemists (1980). Official method of analysis. $13^{\text {th }} \quad$ Edition, Washington D.C.

Canibe, N., Jensen, B.B. (2012). Fermented liquid feed - microbial and nutritional aspect and impact on enteric diseases in pigs. Animal Feed Sci. Technol. 2012; 17-40. Doi: 10.10161. J. Anifeedsci 2011.12.021 [cross reference].

Chock, M., Selby, E. A. D., Cadogan, D.J. and Campbell, R. G. 2004b. effect of liquid feed ratio, Sleeping time and euzyme supplementation on the performance of wearer pigs. Aust.. J. Agri. Res. 55:247 - 252.

Dong, G.Z and Pluske, J. R. 2007. The low feed intake in newly- weaned pigs: problem and possible solutions. Asian - Aust. J. Auim .Sci. 20: $440-452$

El Kasch, B. and Forbes, J.M. (1995). Effect of wet food on the performance of laying hen, British Poult, Sci. 36:839-840.

Hancock, J. D; Hong; J. w. Cabrera, M. R; Hines, R. H and Behnke, K. C. 2002. Corn particule size affects nutritional value of simple and complex dicts for nursery pigs and broiler chicks. Asian- Australas. J. Auim . sci. 15: 872877. 
Han, Y.K., Thacker. P.A. and Yang, J. S. 2006. Effect of durations of Liquid feeding of weaner pigs. Asian - Australas. J. Auim. Sci. 19: 396 - 401

Kornegay, E. T.,H.R. Thomas, D.L. Handlin P.R. Noland and D.K Burbank. 1981. Wet versa dry diets for weaned pigs. J. Auim, Sci $-52: 14-17$.

Lawlor, p.G., G, P.B. lynch, G.E. Gardiner, P.J.Caffrey and J.V.O' Doherty. (2002) .Effect of liquid feeding weaned pigs on growth performance to harvest. J. Anim. Sci. $80: 1725-1735$.

Mc Cracken, K.J., Lilley, J., Mc Allister, A and Ogbonna, J.U. (1994). Effect of heat treatment and enzyme Supplementation on AME content of diets containing cassava and on broiler performance. Proceeding $9^{\text {th }}$ European Conference, Glasglow Vol. 1, August 7$12^{\text {th }}$ 1994. Pp 437-438.

Nwakpu, P.E., Omeje, S.S.I. and Odo. B.I. (1999). Performance of weaner pigs fed diets containing different proportions of dried cassava peels and whole maize. Trop. J, Anim. Sci. 2(2): 81-87.

Nwakpu, P.E., Omeje, S.S.I. and Alaku, S.O. (2000). The response of weaner pigs to diets containing fish meal and blood meal as separate sources of Animal protein. Trop. J. Anim. Sci. 3(1) 45-51.

Nwakpu, P.E. and Otuma, M.O. (2006). Evaluation of early growth performance of backcross progenies from cross bred gilts mated with their native parents. Nig. J. Anim. Prod. 33(2): $170-177$.

Ogbonna, J.U, mcCrahen, k.J, lilley, J, and mc Allister A (1996) effect of processing and enzyme supplementation of cassava root meat on performance of broiler chicks. Nig. J. Anim. prod. 23 (22): 111-115

Ogbonna, J. U, Ogundola, F.I. And Oredein, A.0(2001) effect of wet feed on cockerel chicken performance Nig. J. Anim. Prod. 28 (52-55).

Partridge, G.G., fisher, J., Gregory, H. and Prior, S.G. 1992. Automated wet feeding: of weaner pigs versus conventional dry diet feeding effect of growth rate and feed consumption. Auim, priod. 45(suppl) : 484 (Abstr):

Sola-Oriol, D; Roura, E. and Torrl lardona, D 2009b. Feed preference in pig: particle size and texture. J. Animal Sci. 87:571 582.

Thacker, P. A. 1998. Nutrition requirement of suckling and early weaned pigs. Proc. $8^{\text {th }}$ World Couf. Aumi. Prod Seoul. Korea, PP 312 - 334.

Yalda, A. Y., forbes, J. M., Sainsbury, J, and papasolomontos, s. (1995) Broiler growthand efficiency with wet feed under semi-commercial conditions. Brit.Poult.sci. 36:881Yalda, A.Y and Forbes, J. M. (1995) Effect of wet feeding on the growth of ducts. Brit. Poult. Sci: 36: 878-879. 